Univerzitet u Beogradu
Poljoprivredni fakultet
Institut za poljoprivrednu tehniku
Naučni časopis
POLJOPRIVREDNA TEHNIKA
Godina XLV
Broj 4, 2020.
Strane: $40-50$ $\begin{array}{r}\text { University of Belgrade } \\ \text { Faculty of Agriculture }\end{array}$

\title{
CONSTRUCTION, OPERATION AND MEASURING PROCESS OF TEST REACTOR FOR BIOGAS PRODUCTION
}

\author{
Peter Vindiš $^{* 1}$, Damijan Kelc ${ }^{1}$, Miran Lakota ${ }^{1}$, Peter Berk ${ }^{1}$, Matjaž Ošlaj ${ }^{2}$ \\ ${ }^{I}$ University of Maribor, Faculty of Agriculture and life Sciences, Maribor, Slovenia \\ ${ }^{2}$ Panvita d.d., Rakičan, Murska Sobota, Slovenia
}

\begin{abstract}
The purpose of the research is to build an experimental reactor to study and optimize the production of biogas and its composition from energy crops and other materials of organic origin. An experimental reactor in a biogas plant was constructed for the anaerobic digestion of various substrates. With the experimental reactor, anaerobic digestion can be performed with the basic substrate of pig manure and in different compositions of the substrate. The substrate can be assembled in various combinations of energy crops. The method of construction of the experimental reactor was based on the standard method DIN 38 414, also with the mentioned method we produce biogas under normal conditions from various substrates. The process also determines the quality of biogas or methane content. The built biogas reactor is a reduced version of the economic reactor and serves to optimize the production of biogas in economic conditions.
\end{abstract}

Key words: test reactor, anaerobic fermentation, biogas

\section{INTRODUCTION}

The use of renewable energy sources is becoming increasingly important, as we are increasingly aware of their limitations (especially the limitations of fossil fuels) and their impact on climate change.

\footnotetext{
* Corresponding Author: peter.vindis@um.si

The research work was performed at the biogas plant Ekoteh (Panvita d.d.) as part of the doctoral dissertations of the candidate Matjaž Ošlaj.
} 
In addition to replacing non-renewable sources with renewable ones, efficient use of energy and reduction of its consumption are also important for achieving sustainability and security of energy supply and for reducing greenhouse gas emissions. To achieve these goals, a number of activities are taking place at global, European and national levels. The advantage of using renewable energy sources is reflected in the positive impact on the climate, stability in energy supply and long-term economic benefits. The European Commission estimates that achieving the targets set in the climate energy package by 2020 will mean reducing $\mathrm{CO}_{2}$ emissions by 600 to 900 million tones per year, reducing fossil fuel consumption by 200 to 300 million tonnes per year, reducing the EU's dependence on imported fossil fuels thereby increasing the stability of energy supply in the EU and greater incentives for the development of high-tech industries with new economic opportunities and jobs [1].

Many technologies are known for the direct use and processing of biomass into fuels. They are roughly divided into three groups: incineration, thermal chemical conversion, biological conversion [2].

Natural processes performed by bacteria, yeasts or enzymes in different organic substances under different temperature and oxidation conditions during the fermentation and composting process. Fuels obtained from biomass with the described technologies can also be classified into three groups (SOLID BIOMASS: incineration of wood biomass, waste from agricultural plants and energy crops and algae, LIQUID FUELS FROM BIOMASS: by fermentation into bioethanol, by pyrolysis into biomethanol and from seeds into biodiesel and BIOMASS GASES: by pyrolysis into production of gas and by anaerobic fermentation into biogas [2].

Biogas is a mixture of gases produced during anaerobic fermentation in a device, called a digester or reactor or. fermenter. Anaerobic fermentation is a biological process and is based on methanogenesis. In it, bacteria decompose organic material, and the decomposition product is mainly methane and carbon dioxide. It is generated in the processes of separate treatment of organic waste from agriculture, plant waste and sewage from livestock farming and from the use of purpose-grown biomass for energy production [3]. For the purpose of verifying the biogas potential from various materials, we built a digester and developed appropriate procedures according to which biogas production takes place in economic conditions. The obtained results are useful for biogas production for economic purposes.

\section{MATERIAL AND METHODS}

Near the existing biogas plants, we have set up a test reactor, which will be used to optimize the operation of economical biogas plants and to test new interested substrates for biogas production. The volume of the test reactor is 2500 liters, of which 2000 liters is the working volume and 500 liters is used for gas storage. The test reactor is a scaleddown version of the commercial reactor, as it can test the same treated substrate as in commercial reactors. 
With the test reactor, we obtain more tangible results for a particular substrate compared to the results of various literatures, which mostly cover average results. The obtained results are used directly in economic devices and thus optimize the operation of economic devices and at the same time analyze the actual operation of the test device.

In addition to the test reactor, a 150-liter storage tank was provided for the purposes of homogenizing of certain substrates, sampling and storage of certain substrates.

The construction of a test reactor for the production of biogas from energy crops and other waste materials of organic origin was performed according to the German standard DIN 38 414, part 8 [4]. The standard is useful for determining the course of anaerobic fermentation of various organic substrates, the time course of gas development, the composition of gases as well as the composition of energy plants before and after the fermentation experiment.

At the beginning of the experiment, dry residue (according to DIN 38 414, part 2), organic dry matter (according to DIN 38414 , part 3 ) and pH value (according to DIN 38 414 , part 5) were determined from the experimental substrates investigated. Then dry matter is determinate to the mixture of inoculum (base substrate) and co-substrate (according to DIN 38414 , part 4), organic dry matter and pH value (according to DIN 38414 , part 5), which must be within the basic range ( $\mathrm{pH}$ is from 7 to 8 ). Inoculum is manure from a biogas plant, which serves as inoculum in the process of anaerobic fermentation. Large differences in its composition were observed in several samples of inoculum. Differences in the composition of the manure occur due to different categories (weight) of pigs and the composition of the feed mixtures during the feeding of pigs. According to the deviations in chemical composition, we decided to use one sample of inoculum for credibility in data processing. The inoculum was stored in the pool, where we had the option of storing a sufficient amount of it. To maintain the activity of microorganisms (bacteria) in the inoculum, a small amount $(1 \mathrm{~kg})$ of silage was added for a certain period of time ( 5 days).

Figure 1 shows a sketch of a test reactor filled with inoculum from a biogas plant. The reactor was set to a mesophilic heat range of $37.5^{\circ} \mathrm{C}$ with a tolerance of $\pm 1.5^{\circ} \mathrm{C}$. Mixing was adjusted with a stirrer in the reactor (Figure 1) as in commercial plants. 


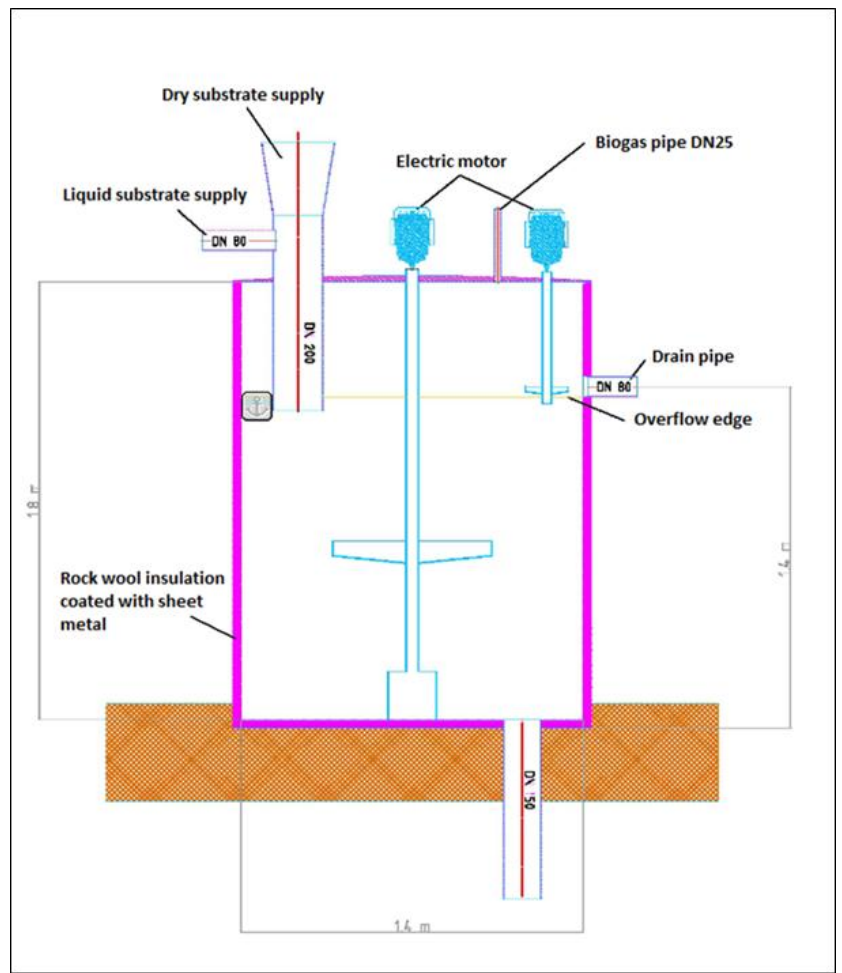

Figure 1. Test reactor

The produced biogas was expressed in norms of liters per unit of substrate $(\mathrm{Nl} / \mathrm{kg}$ $\mathrm{oDM})$ or in norms of cubic meters per ton of organic dry matter $\left(\mathrm{Nm}^{3} / \mathrm{toDM}\right)$. The amount of biogas was recalculated according to normal conditions, i.e. To $=273 \mathrm{~K}$ and Po $=1013 \mathrm{mb}[4]$.

The normal volume is the volume of gas produced from the various substrates. To evaluate the data, it is first necessary to perform the calculation of the normal volume in individual time periods of the developed biogas, with the equation:

$$
V o=V \cdot \frac{(P l-P w) \cdot T o}{P o \cdot T}
$$

where:

Vo - standard (normal) volume of biogas in $\mathrm{ml}$;

$V$ - measured volume of biogas in $\mathrm{ml}$;

$P l-$ air pressure at the time of measuring in mbar;

$P w$ - water vapor pressure as a function of room temperature in mbar;

To - norm temperature To $=273 \mathrm{~K}$;

$P o-$ norm pressure $\mathrm{Po}=1013$ mbar;

$T$ - temperature of biogas or surrounding space in $\mathrm{K}$. 
The proportion of fission gas production is then calculated with the equation:

$$
V_{i s}=\frac{\sum V_{i s} \cdot m_{i s}}{m_{M}}
$$

where:

$V_{i s}$ - the volume of gas developed from the inoculum (inoculum is largely fermented sludge that is kept biologically active by the regular addition of small amounts of raw sludge), in $\mathrm{ml}$; .

$\Sigma V_{i s}$-the sum of the volume of gas in the experiment with inoculum in $\mathrm{ml}$;

$m_{i s}-$ mass of inoculum used for mixtures in $\mathrm{kg}$;

$m_{M}-$ mass of inoculum used in the control experiment in $\mathrm{kg}$.

The specific production of biogas or inoculum is calculated gradually from reading to reading according to the equation:

$$
V s=\frac{\sum V n \cdot 10^{4}}{m \cdot W t \cdot W v},
$$

where:

$V s$ - specific biogas production in the norm of liters of biogas per kilogram of organic dry matter $(\mathrm{Nl} / \mathrm{kg} \mathrm{oDM})$;

$\Sigma V_{n}-$ net volume of gas produced from inoculum during the observation time in $\mathrm{ml}$;

$m$ - the mass of the weighed sample of inoculum (inoculum of this standard is raw sludge) in $\mathrm{kg}$;

$W_{t}$ - the dry residue of the test sample of the reference sludge (inoculum) in \%;

$W_{v}-$ the loss of dry mass combustion of the inoculum in the experiment in $\%$.

Based on the estimated yield of fresh mass of the energy crop, we calculate the yield of dry matter and organic dry matter in $\mathrm{kg} / \mathrm{ha}$, taking into account the results of chemical analysis for dry matter and organic dry matter according to the equation:

$$
P S S=\frac{S M \cdot S S}{100}
$$

where:

$P S S$ - dry matter yield in $\mathrm{kg} / \mathrm{ha}$;

$S M$ - fresh mass yield in $\mathrm{kg} / \mathrm{ha}$;

$S S$ - dry matter of the substrate in $\%$. 
The yield of organic dry matter of an individual energy plant was calculated according to the equation:

$$
P o S S=\frac{P S S \cdot W v}{100}
$$

where:

PoSS - organic dry matter yield in $\mathrm{kg} / \mathrm{ha}$;

$P S S$ - dry matter yield in $\mathrm{kg} / \mathrm{ha}$;

$W v$ - dry annealing losses in $\%$.

Then we calculate the biogas yield $\left(\mathrm{Nm}^{3} / \mathrm{ha}\right)$ based on the results of measurements of the amount and composition of produced biogas by individual energy plants according to the equation:

$$
P B=\frac{P o S S \cdot B}{1000}
$$

where:

$P B$ - biogas yield in $\mathrm{Nm}^{3} /$ ha;

$P o S S$ - organic dry matter yield in $\mathrm{kg} / \mathrm{ha}$;

$B$ - biogas yield in $\mathrm{Nl} / \mathrm{kg}$ oDM.

The yield of biomethane (N1/kg oDM) is calculated by multiplying the calculation of the specific production of biogas or inoculum (equation 3 ) by the amount of methane produced.

$$
B M=\frac{V s \cdot V}{100}
$$

where:

$\mathrm{BM}$ - biogas yield in N1/kg oDM;

$\mathrm{Vs}$ - specific biogas production in norms of liters of biogas per kilogram of organic dry matter $(\mathrm{Nl} / \mathrm{kg} \mathrm{oDM})$;

$\mathrm{V}$ - methane content in \%. equation:

The yield of biomethane $\left(\mathrm{Nm}^{3} / \mathrm{ha}\right)$ for an individual energy plant is calculated by the

$$
P B M=\frac{P o S S \cdot P M}{1000}
$$

where:

$P B M$ - biomethane yield in $\mathrm{Nm}^{3} /$ ha;

$P o S S$ - organic dry matter yield in $\mathrm{kg} / \mathrm{ha}$;

$P M$ - biomethane yield in $\mathrm{Nl} / \mathrm{kg}$ oDM. 


\section{RESULTS AND DISCUSSION}

Table 1 shows and describes the components of the experimental reactor. The amount of biogas produced was measured using a biogas flow meter. We also had to determine the maximum reactor load. For this we used the corn silage that we had the most at our disposal, and we know a lot about it from the literature. The load of the test reactor for the anaerobic digestion process was performed with 54 liters of slurry (base substrate) and $20 \mathrm{~kg}$ of silage (substrate). Using a pump with an electric motor (Figure $3 \mathrm{c})$, we pumped the slurry into the test reactor.

Table 1. Components of the experimental reactor

\begin{tabular}{|c|c|}
\hline Components & Component properties \\
\hline Stirrer & $\begin{array}{l}\text { Horizontally at two heights, it is powered by a } 500 \text { W electric } \\
\text { motor (Figure 2). }\end{array}$ \\
\hline $\begin{array}{l}\text { Heater (heating } \\
\text { pipes) }\end{array}$ & $\begin{array}{l}\text { It is installed inside on the walls of the reactor, it is heated by } \\
\text { hot water from the heat exchanger (Figure 2). }\end{array}$ \\
\hline $\begin{array}{l}\text { Additional stirrer } \\
\text { at the outlet }\end{array}$ & $\begin{array}{l}\text { Horizontal mixer, height-adjustable in overflow edge, which } \\
\text { prevents clogging at the outlet. It is powered by a } 350 \mathrm{~W} \text { motor } \\
\text { (Figure } 3 b) \text {. }\end{array}$ \\
\hline $\begin{array}{l}\text { Slurry } \\
\text { pump }\end{array}$ & $\begin{array}{l}\text { An electric motor pump with which we pump manure into the } \\
\text { reactor. Taking into account the losses in the pipeline, it pumps } \\
2 \text { liters of slurry into the reactor per minute (Figure } 3 c \text { ). }\end{array}$ \\
\hline $\begin{array}{l}\text { Hopper for dry } \\
\text { substrates }\end{array}$ & $\begin{array}{l}\text { Funnel-shaped opening into which dry substrates are poured at } \\
\text { certain intervals (Figure 2). }\end{array}$ \\
\hline Biogas flow meter & $\begin{array}{l}\text { A mechanical meter that records the flow of biogas based on } \\
\text { blade turns driven in our case by biogas (Figure } 3 a \text { ). }\end{array}$ \\
\hline $\begin{array}{l}\text { Analyzer of } \\
\text { biogas quality }\end{array}$ & $\begin{array}{l}\text { Portable biogas analyzer, with which we analyze the quality of } \\
\text { biogas at certain intervals or as needed. We can measure the } \\
\text { values of } \mathrm{CH}_{4}, \mathrm{CO}_{2}, \mathrm{O}_{2} \text { in percent and the value of } \mathrm{H}_{2} \mathrm{~S} \text { in ppm } \\
\text { (Figure } 4 d) .\end{array}$ \\
\hline
\end{tabular}

Computer control All devices on the reactor, except the biogas quality analyzer, box are controlled by a computer via a control box (Figure 4).

Other equipment Laboratory with all necessary equipment and other equipment for storage and handling of substrates.

Sampling points They are at the six outlets of the ball valve reactor, where samples can be taken for analysis at different depths. Of these six discharges, two are $80 \mathrm{~mm}$ in diameter (Figure 2).

Window

A place with a glass door, through which we can observe what is happening in the reactor from the top.

Stirrer outflow $\quad$ Stirrer for draining fermented manure. 
Figure 2 shows an experimental reactor designed for the purpose of biogas production from various substrates.

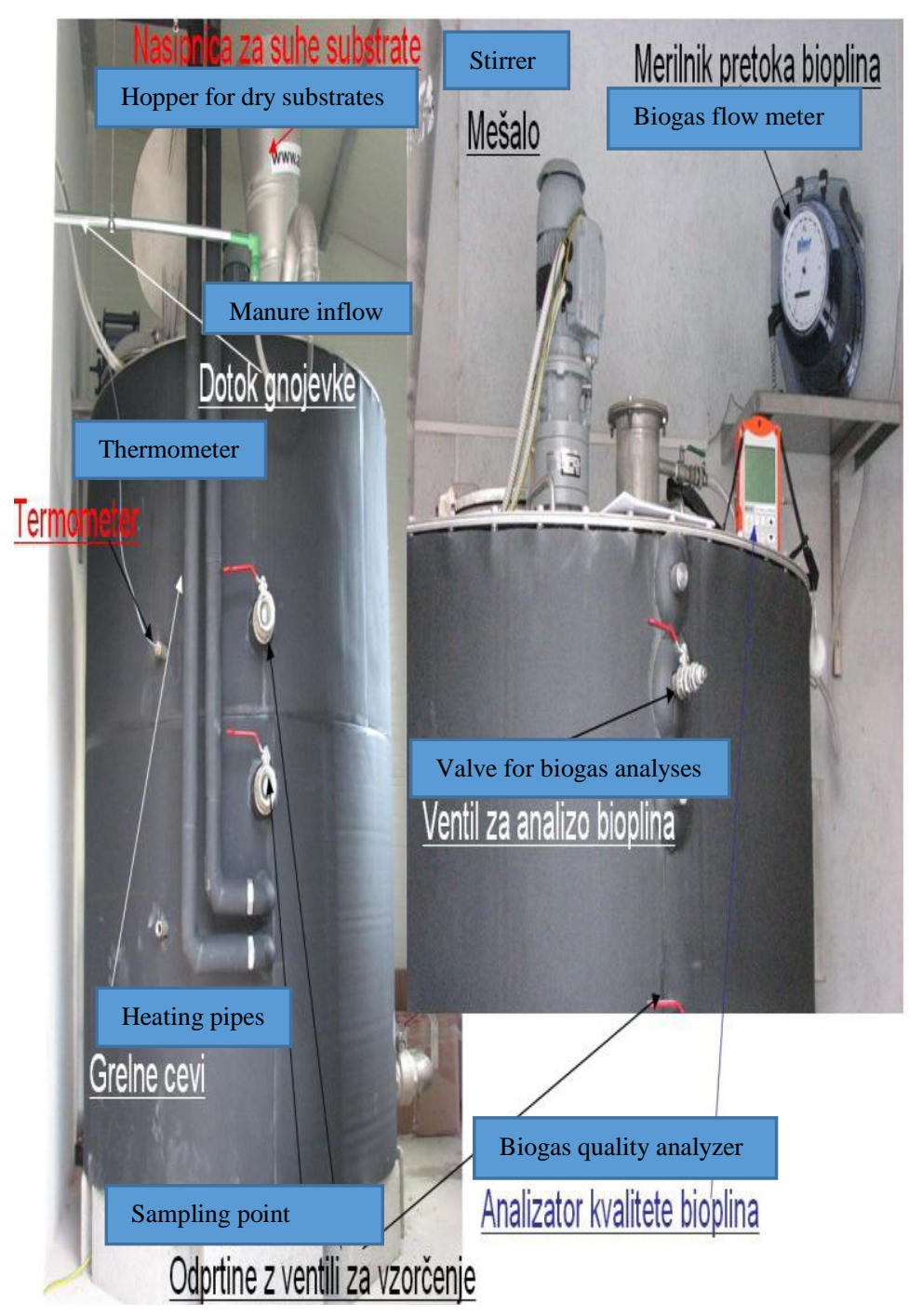

Figure 2. Experimental reactor 


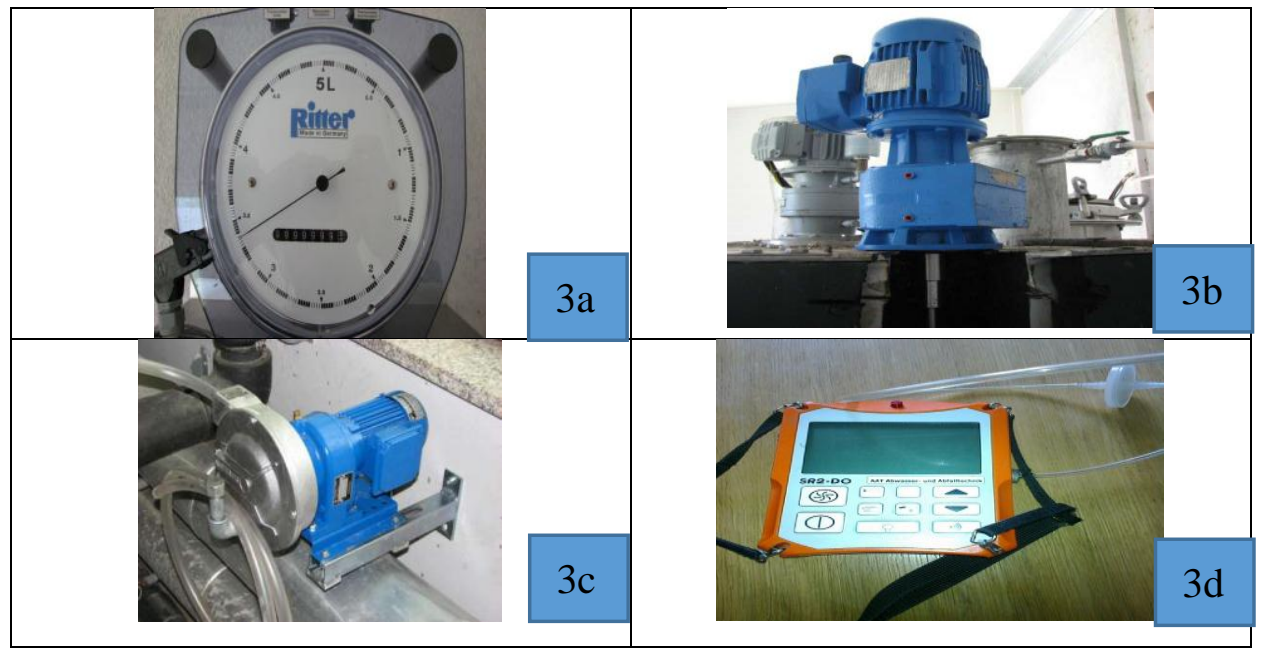

Figure 3. Different components of experimental reactor

Each sample tested contained the same amount of slurry (54 1 of basic substrate) and silage (20 kg of substrate) daily. The amount of biogas produced was monitored continuously and recorded in a computer program every 12 seconds (Figure 4). Biogas quality was measured three times a week with a portable SR2 - DO analyzer (Figure 3d). We measured the values of $\mathrm{CO}_{2}, \mathrm{O}_{2}, \mathrm{CH}_{4}$ in percent and the value of $\mathrm{H}_{2} \mathrm{~S}$ in ppm.

Reactor control (Figure 4) is automated through a control system that includes regulation, measurement and monitoring of biogas yield. The software is used to view and set the time control of the mixer, slurry pump, biogas flow meter, heater and biogas yield monitoring.

For each sample tested, we also performed titration to determine volatile fatty acids (VFA), according to the AAT procedure (AAT Biogas Technology 2007). The chemical titration process was performed using laboratory instruments such as: titration burette (for stepwise dosing, $0.02 \mathrm{ml}$ each), pipette, magnetic stirrer, $\mathrm{pH}$ meter with thermometer, $250 \mathrm{ml}$ beaker and blower. Samples were titrated with $0.05 \mathrm{M}$ sulfuric (VI) acid, and a sample for titration was first prepared before titration. To this was added 120 $\mathrm{mL}$ of distilled water in a $5 \mathrm{~mL}$ sample. The sample beaker was placed on a magnetic stirrer, the temperature and initial $\mathrm{pH}$ of the sample were measured, and titration was started. This data was finally entered into a table in Excel and the value of volatile fatty acids (VFA) was calculated. 


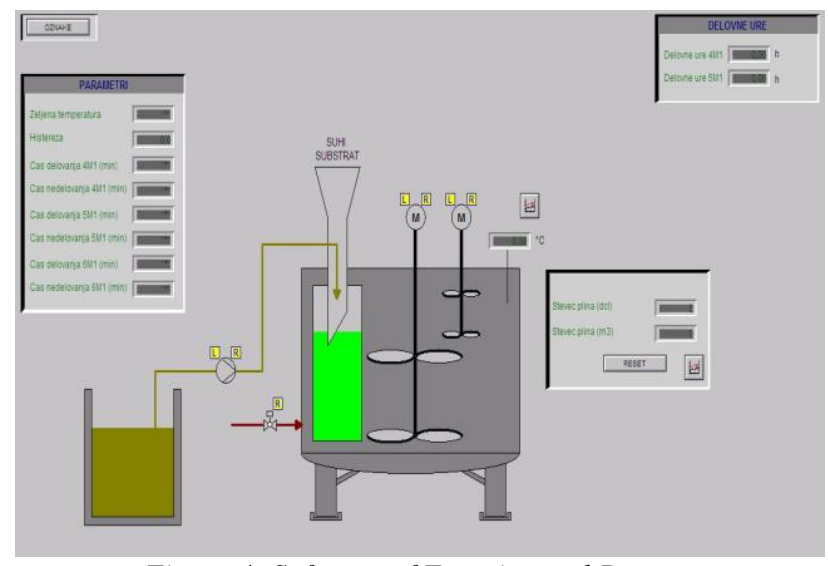

Figure 4: Software of Experimental Reactor

Anaerobic digestion is carried out with the basic substrate of pig manure and in different compositions of the substrate. For co-substrates, we used maize (main crop), maize (stubble crop), triticale (main crop), sorghum (main crop), a mixture of plants for biomass production (main crop) and maize as grain (grain at the waxy maturity stage). The substrates can be composed in various combinations of plant species in anticipation of high biogas yield. The test reactor can be used for biogas testing of other different organic waste materials (waste, water). Some results measuring biogas with experimental digester from various energy crops can be seen in different literature [5-6].

\section{CONCLUSIONS}

The production of biogas with anaerobic fermentation is one of the technologies that can contribute towards energy production, sustainable waste management and the reduction of greenhouse gas emissions. In order to optimize the anaerobic fermentation process of new substrates for biogas production, we build an experimental reactor and developed method for producing biogas from various energy crops and other organic waste materials. The built biogas reactor is a smaller version of the economic reactor and it works in a mesophilic temperature range as economical biogas plant.

The main purpose of the pilot reactor is to test the biogas potential of new economically interesting substrates, optimize the biogas production process and eliminate possible problems during production before using the new substrate in a commercial biogas plant.

\section{REFERENCES}

[1] Statistical Office of the Republic of Slovenia. European Sustainable Energy Week, 2012. electronic source. Available: https://www.stat.si/novica_prikazi.aspx?id=4754 [05. 10. 2014]. 
[2] Medved S., Novak P. 2000. Biomasa. V: Varstvo okolja in obnovljivi viri energije. Ljubljana, Fakulteta za strojništvo: str.231 .

[3] Nekrep FV. 2002. Seminar odstranjevanja odpadkov. Anaerobni postopki čiščenja odpadnih vod, Ljubljana: str. 32 .

[4] DIN 38 414, del 8. 1985. Deutsche Norm (Schlamm und Sedimente - Grupe S).

[5] Ošlaj, M., Kraner-Šumenjak, T., Lakota, M., Vindiš, P. 2019. Parametric and nonparametric approaches for detecting the most important factors in biogas production. Polish Journal of environmental studies. vol. 28, no. 1, pp. 291-301.

[6] Ošlaj, M. 2017. Razvoj modela sestave različnih rastlinskih substratov za proizvodnjo bioplina : doktorska disertacija $=$ Developing a model for the composition of various plant substrates for biological production : Ph.D. thesis. Maribor: str.113 .

\title{
PROCES IZGRADNJE, RADA I MERENJA TEST REAKTORA ZA PROIZVODNJU BIOGASA
}

\author{
Peter Vindiš ${ }^{1}$, Damijan Kelc ${ }^{1}$, Miran Lakota ${ }^{1}$, Peter Berk ${ }^{1}$, Matjaž Ošlaj ${ }^{2}$ \\ ${ }^{1}$ University of Maribor, Faculty of Agriculture and life Sciences, Maribor,R.Slovenia \\ ${ }^{2}$ Panvita d.d., Rakičan, Murska Sobota, R.Slovenija
}

Sažetak: Svrha istraživanja je izgradnja eksperimentalnog reaktora za proučavanje i optimizaciju proizvodnje biogasa i njegovog sastava iz energetskih useva i drugih materijala organskog porekla. Izveden je eksperimentalni reaktor u postrojenju za biogas za anaerobnu digestiju različitih supstrata. Sa eksperimentalnim reaktorom, anaerobna digestija se može izvršiti sa osnovnom podlogom stajnjaka od svinja i različitim sastavima substrata. Podloga (substrat) može se sastaviti od različitih kombinacija energetskih useva. Način izrade eksperimentalnog reaktora zasnovan je na metodi standarda DIN 38 414. Takođe pomenutom metodom mi proizvodimo biogas u normalnim uslovima iz različitih podloga. Proces takođe određuje kvalitet sadržaja biogasa ili metana. Izgrađeni reaktor za biogas je redukovana verzija ekonomskog reaktora i služi za optimizaciju proizvodnje biogasa u ekonomskim uslovima.

Ključne reči: test reaktor, anaerobna fermentacija, biogas

Prijavljen:

Submitted: 07.11 .2020

Ispravljen:

Revised: $\quad 18.11 .2020$.

Prihvaćen:

Accepted: 07.12 .2020 . 